Kalem Eğitim ve İnsan Bilimleri Dergisi 2017, 7(2), doi: 10.23863/kalem.2018.88

\title{
Öğretmenlerin Zihinsel Yetersizliği Olan Öğrencilerin Matematik Becerilerini Değerlendirme Sürecinde Yaptıklarının Belirlenmesi ${ }^{1}$
}

\author{
Arş. Gör. Serdar SÖNMEZ* \\ Abant İzzet Baysal Üniversitesi, Eğitim Bilimleri Enstitüsü, Gölköy Yerleşkesi, Bolu / Türkiye, \\ serdarsonmez@live.com, ORCID: 0000-0002-9050-3570 \\ Yrd. Doç. Dr. Ahmet YIKMIŞ \\ Abant İzzet Baysal Üniversitesi, Eğitim Fakültesi, Gölköy Yerleşkesi, Bolu / Türkiye, \\ ayikmis@hotmail.com, ORCID: 0000-0002-1143-1207
}

\section{Öz}

$\mathrm{Bu}$ araştırmanın amacı; öğretmenlerin, zihinsel yetersizlik tanısı almış öğrencilerin matematik beceri, kavram ve işlemlerini değerlendirme sürecinde yaptıklarını belirlemektir. Bu araştırmada nitel araştırma yöntemlerinden durum çalışması deseni kullanılmıştır. Veriler, görüşme yöntemi içerisinden yarı yapılandırılmış görüşme tekniği kullanılarak toplanmıştır. Araştırmanın katılımcılarını, 2013-2014 eğitim öğretim yılında Bolu il merkezinde ve merkez ilçelerinde bulunan Millî Eğitim Müdürlügü’ne bağlı ilkokul ve özel eğitim okullarında görev yapan 21 öğretmen oluş-

\footnotetext{
${ }^{1}$ Bu araştırma, birinci yazarın Abant İzzet Baysal Üniversitesi Eğitim Bilimleri Enstitüsü Özel Eğitim Ana Bilim Dalı'nda sunduğu yüksek lisans tez çalışmasından üretilmiştir. Ayrıca 24. Ulusal Özel Eğitim Kongresi'nde sözlü bildiri olarak sunulmuş ve kongre kitabında özet olarak basılmıştır.

* Sorumlu Yazar. Tel: +90 3741000 - 2477

(C) 2017 Kalem Eğitim ve Sağlık Hizmetleri Vakfı. Bütün Hakları Saklıdır. ～ISSN: 2146-5606
} 
turmaktadır. Araştırmada elde edilen veriler içerik analizi tekniği ile analiz edilmiştir. Araştırmaya katılan sınıf öğretmenlerinin kişisel bilgileri hakkında veri toplamak amacıyla görüşme öncesinde yazılı olarak doldurmaları için kişisel bilgi formu geliştirilmiştir. Araştırmanın bulguları, öğretmenlerin büyük çoğunluğunun zihinsel yetersizliği olan öğrencilerin matematik performanslarını öğretim öncesi, anı ve sonrasında değerlendirdiklerini göstermektedir. Öğretmenlerin değerlendirme sürecinde materyal ve ortam üzerinde bazı uyarlamalar yaptı̆̆ı ve bu uyarlamaları yaparken de öğrenci özelliklerini göz önünde bulundurdukları tespit edilmiştir. Ayrıca değerlendirme aşamasında öğretmenlerin bazı sorunlarla karşılaştıkları bulgusu elde edilmiştir. Bu sorunların ortadan kaldırılmasına yönelik çözüm ürettikleri görülmüştür.

Anahtar Kelimeler: Zihinsel yetersizlik; Matematik; Beceri; İşlem; Değerlendirme.

\title{
Defining Teachers' Practices in the Assessment for Mathematical Abilities of Students with Mental Disability
}

\begin{abstract}
The aim of this study is to identify teachers' practices in the assessment process for mathematical abilities, concepts and operations at students with mental disability. From qualitative research methods, case studies design was used in this study. Data were collected using semi-structured interviews in the interview process. Participants of this study consisted of twenty one teachers who work in primary and special education school located in the city center of Bolu in 2013-2014 school year. The research data was analyzed according to content method. Personal information form was developed for gathering personal information about the teachers. The findings of the research shows that the majority of teachers assess students' math performance before, during and after instruction. It is found that teachers make some adaptations on material and environment. Teachers take into consideration students' characteristics when they make these adaptations. Also, it is found that teachers face some problems and they try to resolve these problems.
\end{abstract}

Keywords: Mental disability; Mathematics; Ability; Concept; Assessment. 


\section{Extended Summary}

\section{Purpose}

The purpose of this study is to identify teachers' practices in the assessment process for mathematical abilities, consept and operations of students with mental disability.

\section{Method}

The case study pattern among qualitative research methods was used in this study. The data were collected using the interview method. The semi-structured interview technique among the interview methods was used. The participants of the study consist of teachers working at primary schools and special education schools affiliated to the Ministry of National Education in Bolu province center and central districts in the 2013-2014 school year. 21 teachers working on mathematics teaching with students diagnosed with mental disability, currently, were determined. A code name was determined for each teacher in the study, and the real names were not used at any stage of the study. The interview questions were prepared using the semi-structured interview technique by examining the studies carried out in the literature in order to collect the research data and taking the opinions of the experts. The data obtained in the study were analyzed using the content analysis technique. The interview questions were mainly used in the creation of the categories.

\section{Result}

It is seen that the majority of the teachers prepare the materials in a way that suits the students. It was revealed that three teachers vary their materials in order not to let students memorize and get bored, while two teachers do not make any adaptation in the materials. It is seen that six teachers make adaptation by removing the distracting stimulants from the environment, three teachers work personally with their students and one teacher makes an adaptation in the environment by grouping the students by their levels. Eleven teachers expressed that they did not make an adaptation in the environment as their class is not suitable. Apart from one of the teachers, all other teachers expressed that they make a material or environment adaptation by taking the properties of the students into consideration. One teacher that does not take the adaptations into consideration is included in this category since material and environment adaptation is not made. It is seen that thirteen teachers make corrections by revising their own practices from the mistakes made by the students, five teachers by making certain corrections to the students, and three 
teachers used their own corrections from the mistakes made by 9 students with their own directions. Some of the teachers said that they encountered a single problem, some said that they encountered more than one problem, while two teachers expressed that they did not encounter any problem. The distraction of the students, that students are not interested in the study, the lack of tools and materials, the unsuitability of the classroom environment, the insufficiency of time, that students forget what is taught, that there are students at different levels and teachers cannot get down to the level of students are among the main reasons. It is seen that teachers intervene in the problems they encounter with different solution suggestions. Among these solution suggestions are, working in cooperation, collecting the attention of students, making the study attractive, materializing the study, taking materials, changing the material, enriching the material, changing the environment, repeating the instruction and awarding.

\section{Discussion}

That teachers make changes in the process of assessment both in the form of material and environment adaptations is an important phenomenon for the assessment. It is interesting that one of the two teachers that do not make any adaptation in the materials has graduated from outside the field and has not received any training on mathematics teaching, while another teacher has again graduated from outside the field, but has received his master's degree in the field of special education. Ten of the teachers expressed that they could not make any adaptation as their classes are small in size but crowded in terms of the number of students. Here, it can be concluded that the schools are old in structure, created later on, or the buildings are not built in line with their purposes. It is believed that the fact that teachers pay attention to the adaptations is important for the assessment process to be effective. It is believed that taking the mistakes made by students into consideration contributes to teachers significantly in terms of developing the program. From the statements made by the teachers participating in the study, it is understood that they sufficiently benefit from the mistakes that students with special needs make in mathematical skills, concepts or processes, and use them in individualizing the program and developing the individualized program. It is believed that teachers have problems in reaching the students as a result of the problems they encounter. That a great majority of teachers show effort for overcoming the problems makes people think that they are willing to do whatever they can for students with special needs. These behaviors of teachers may be important 
in terms of effective assessment practices.

\section{Conclusion}

Consequently, teachers are aware of the importance of the assessment process in making the decisions of teaching a new skill, concept or process. The data obtained show that teachers show the necessary care in terms of assessing the mathematical skills, concepts or processes of mentally disabled students. It is seen that teachers try to overcome the problems they encounter at the assessment stage with their own efforts. However, they emphasize that the assessment studies may become better in case the necessary support is provided, and it will be a more effective study for students with special needs.

\section{Giriş}

Matematik, günümüz dünyasında evrensel bir dil olması sebebiyle birey ve toplum için son derece önemli ve vazgeçilmez bir alandır. Günlük yaşamda kullanmak için gereksinim duyduğumuz iletişim kurabilme ve yaratıcı düşünme gibi davranışları geliştiren bir alan olması da matematiğin öğrenilmesi adına kaçınılmazdır (Akkaya, 2006). Matematik becerileri günlük yaşantımızda yoğun olarak kullandığımız becerilerdendir. Matematik, insanların günlük yaşamlarının birçok alanında karşılarına çıkmakta ve matematik becerileri insanların yaşamlarını kolaylaştırmaktadır. Günlük yaşantımızda alışveriş, zaman ve işlem yapma alanlarında matematiği sıklıkla kullandığımızı düşünecek olursak, zihinsel yetersizliği olan bireylere bu matematik becerilerinin öğretimi, onların yaşamlarını bağımsız olarak sürdürmelerine imkân sağlayacaktır (Karabulut ve Y1kmış, 2010).

Zihinsel yetersizliği olan bireylere matematik beceri, kavram ve işlem öğretimlerinin etkili bir şekilde gerçekleştirilmesi gerekmektedir. Diğer yetersizliği olan bireyler için de gerekmektedir. Etkili bir öğretim için de öğrencilerin öğretim öncesi, anı ve sonrasında değerlendirilmelerine ihtiyaç duyulmaktadır. Öğretmenlerin, özel gereksinimli öğrencilerin eğitim-öğretimden en iyi şekilde faydalanabilmeleri için sadece öğretim programını planlanma sürecine değil ayrıca değerlendirme sürecine de önem vermeleri beklenmektedir (Güven, 2009). Programı planlarken yapılan değerlendirmeler, öğrencilerin işlevde bulunma düzeylerini belirlemek için yapı1ır. İşlevde bulunma düzeyleri de amaçların belirlenmesine ve belirlenen amaçların gerçekleştirilmesine yönelik öğretim etkinliklerinin oluşturulmasina yardımcı olur (Kırcaali-İftar, 1996). 
Öğrenci başarılarının öğretim öncesi, anı ve sonrası sürekli olarak değerlendirilmesiyle birçok veri elde edilmektedir. Elde edilen bu veriler öğrencilerin, performanslarının belirlenmesi, uygun eğitim ortamına yerleştirilmeleri, özel eğitim hizmetlerinin belirlenmesi, öğretim programlarının hazırlanması, ilerlemelerin ve değişikliklerin takip edilmesi, uygulanan programın etkililiğinin belirlenmesi, başka bir programa geçiş kararlarının verilmesi ve öğrenci, öğretmen ve ebeveyn arasında sağlıklı bir iletişimin kurulması konularında öğretmenlere katkı sağlamaktadır (Bryant, Smith ve Bryant, 2008). Bu nedenle özel gereksinimli öğrencilerin öğretim öncesinde, anında ve sonrasında değerlendirilmeleri öğretim sürecinin vazgeçilmez bir ögesi olarak büyük önem arz etmektedir.

Salvia ve Ysseldyke'e (1988) göre değerlendirme "problemleri belirlemek için bilgi toplama ve eğitsel hedefler belirleme" olarak tanımlanırken, Taylor (2006) "bireysel hedefleri belirlemede yardımcı olan faydalı bilgileri toplama” olarak tanımlamaktadır. Gürsel'e (2010) göre ise "öğrencilerin akademik, davranışsal ya da fiziksel özelliklerini belirlemek ve bu özelliklere uygun yasal ve eğitsel kararlar alabilmek amactyla veri toplama süreci" olarak tanımlanmaktadır.

Özel eğitimde değerlendirme her zaman kritik bir rol oynamasına rağmen, No Child Left Behind Act'in (NCLB) 2001 y1lındaki, öğrencilerin yıllık standart değerlendirilmesi yoluyla öğrenci başarılarını geliştirmeyi amaçlayan bildirisiyle öğrenciler ve okul personeli için değerlendirmenin önemi çarpıcı bir biçimde artmıştır (Smith, Polloway, Patton ve Dowdy, 2008).

Uzmanlar tarafından yapılan kapsamlı bir değerlendirme, öğrencinin eğitim hayatının herhangi bir yönüne yol gösterebilir (Huebner, 2000). Eğitim ortamlarında çok farklı rollerde yer alabilmelerinden dolayı özel eğitimcilerin eğitimdeki konumu eşsizdir. Rolleri ne olursa olsun özel eğitimciler, pratik fikirler ve uygun öneriler gerektiren çok çeşitli durumlarla karşı karşıya gelmektedirler. Özel eğitimde hangi alanda uzman olunursa olunsun, değerlendirme sürecini tam anlamıyla anlamak ve hayati öneme sahip bilgileri diğer uzmanlar, aileler ve öğrencilerle açık bir şekilde iletişim kurarak paylaşmak her zaman son derece önemlidir (Pierangelo ve Giuliani, 2009).

Değerlendirme uygulamalarının temel amacı öğretimin etkililiğini saptamak için veri toplamaktır. Böylece uygun öğretim uyarlamaları yapılabilmektedir (Cawley ve Parmar, 2003). 
Alanyazın incelendiğinde, yurtdışındaki araştırmacılar tarafından özel gereksinimli öğrencilerin becerilerinin değerlendirilmesini konu alan sınırlı sayıda çalışma olduğu görülmektedir. Eckert, Dunn, Codding, Begeny ve Kleinmann (2006), matematik ve okuma performanslarının değerlendirilmesini, Hanzlicek (2006), ağır derecede zihinsel yetersizliği olan öğrencilerin öğretimlerinin planlaması ve alternatif değerlendirilmesi sürecinde özel eğitim öğretmenlerinin görüşlerini, Hall (2002), öğretmenlerin, özel gereksinimli öğrencilerin akademik derslerdeki performanslarının değerlendirilmesinde sınav uyarlamalarını nasıl yaptıklarını araştırmıştır. Türkiye'de ise zihinsel yetersizliği olan öğrencilerin becerilerinin değerlendirilmesini konu alan çalışmaların çok sınırlı olduğu görülmektedir. Güven (2009), ilköğretimde kaynaştırma uygulamalarına katılan zihinsel yetersizliği olan öğrencilerin başarılarının değerlendirilmesine ilişkin öğretmen görüşlerini araştırmıştır. Öğretmenlerin, zihinsel yetersizliği olan öğrencilerin matematik becerilerini değerlendirme sürecinde yaptıklarının belirlenmesini inceleyen bir araştırmaya rastlanmaması ve değerlendirme sürecinin daha iyi yapılabilmesi için bu araştırmaya gereksinim olduğu düşünülmüştür

Günlük hayatta sıklıkla kullanılan ve karşılaşılan beceriler arasında matematik becerileri de yer almaktadır. Temel hesaplama ve alışveriş gibi hayatımızı kolaylaştıran becerileri yerine getirebilen bireylerin toplum içerisinde yaşamlarını bağımsız bir şekilde sürdürebiliyor olmaları bireylere matematik beceri, kavram ve işlemlerinin öğretilmesi gerekliliğini ortaya çıkarmaktadır. Öğretmenlerin etkili bir öğretim gerçekleştirebilmesi için öğretim öncesi, anı ve sonrası değerlendirme süreçlerinde yaptıklarının ortaya konması açısından önemli görülmektedir.

Çalışmada öğretmenlerin değerlendirme sürecinde ortaya koydukları uygulamaların incelenmesinin, başarılı matematik öğretimi ve öğretim öncesi, anı veya sonrasında ortaya çıkabilecek problemlere yönelik çözüm önerileri için öğretmenlere yardımcı olabileceği düşünülmektedir.

Araştırma, zihinsel yetersizliği olan öğrencilerin matematik beceri, kavram ve işlemlerinin değerlendirilme sürecinin öğrenciler için daha etkili ve daha verimli olması hususunda katkı sağlayabilir. Ayrıca sadece zihinsel yetersizliği olan öğrencilerin değil diğer yetersizliğe sahip öğrencilerin değerlendirilmesinde de öğrenciler adına iyi sonuçlar alınabileceği düşünülmektedir.

Değerlendirme sürecinin etkili bir şekilde uygulanması öğretim süre- 
cinin de daha verimli olmasına olanak sağlamaktadır. Her iki süreci de verimli şekilde geçiren öğrenciler matematik becerilerini günlük yaşamda daha s1k kullanabilirler. Zihinsel yetersizliği olan öğrencilerin günlük hayatta matematik becerilerinde başarılı olmaları toplumun yetersizlikten etkilenmiş bireylere bakış açılarını değiştirebilir. Bu nedenle çalışmanın toplumsal açıdan önemli olduğu düşünülmektedir.

Araştırmanın ilgili alanyazına öğretmenlerin zihinsel yetersizlik tanısı almış öğrencilerin matematik beceri, kavram ve işlemlerini değerlendirme sürecinde, öğretim öncesi, anı ve sonrasında ne tür uygulamalar yaptığı, bu uygulamalar esnasında karşılaştıkları problemler ve bu problemlere yönelik ürettikleri çözümler açısından katkı sağlayacağı düşünülmektedir.

$\mathrm{Bu}$ araştırmanın amacı; öğretmenlerin, zihinsel yetersizliği olan öğrencilerin matematik beceri, kavram ve işlemlerini değerlendirme sürecinde yaptıklarını belirlemektir. Bu amaç ışığında aşağıdaki sorulara yanıt aranmıştır, öğretmenler:

1. Değerlendirme süreçlerinde ne tür uyarlamalar yapmaktadırlar ve uyarlamaları yaparken nelere dikkat etmektedirler?

2. Öğrenci hatalarından nasıl yararlanmaktadırlar?

3. $\mathrm{Bu}$ süreçte ne tür sorunlarla karşılaşmaktadırlar ve bu sorunların çözümüne ilişkin neler yapmaktadırlar?

\section{Yöntem}

$\mathrm{Bu}$ araştırmada nitel araştırma yöntemlerinden durum çalışması deseni kullanılmıştır. Veriler görüşme yöntemi kullanılarak toplanmıştır. Görüşme yöntemi içerisinde en çok kullanılan, derinliğine ve zenginliğine veri sağlaması, bu araştırmanın da amacının gerçekleştirilmesine yönelik veri sağlayabilecek tekniklerden birisi olması nedeniyle yarı yapılandırılmış görüşme tekniği kullanılmıştır.

Yarı yapılandırılmış görüşme, eğitim araştırmacılarınca en çok tercih edilen görüşme tekniği olup, yapılandırılmış görüşmenin çok daha esnek bir biçimidir. Konu alanında araştırmacının aydınlatmak istediği alana dayanan açık uçlu soruları içerir (Karasar, 2003). Hem sabit seçenekli yanıtlamayı hem de ilgili alanda derinlemesine gidebilmeyi birleştirir. Görüşmeci, görüşülenin yanıtlarından hareketle soracağı soruları daha da açarak cevapları ayrıntılı hâle getirebilir (Büyüköztürk, Çakmak, Akgün, Karadeniz ve Demirel, 2009). 
$\mathrm{Bu}$ çalışmada da öğretmenlerin zihinsel yetersizlik tanısı almış öğrencilerin matematik beceri, kavram ve işlemlerini değerlendirme sürecine ilişkin yaptıklarının belirlenmesi hakkında daha ayrıntılı bilgi toplamak amaciyla veriler yarı yapılandırılmış görüşme tekniğiyle toplanmıştır.

Araştırmanın katılımcılarını, 2013-2014 eğitim öğretim yılında Bolu il merkezinde ve merkez ilçelerinde bulunan Millî Eğitim Müdürlüğü'ne bağlı ilkokul ve özel eğitim okullarında görev yapan öğretmenler oluşturmaktadır.

Çalışma grubunun belirlenmesi amacıyla Bolu İl Millî Eğitim Müdürlüğü ve Bolu Valiliğinden alınan izinle okul yöneticilerine araştırmanın amacı ve nasıl uygulanacağı hakkında bilgi verilmiştir. Okul yöneticilerinin izni alınarak öğretmenlerle görüşülmüştür. Bu görüşmelerde yine araştırma hakkında öğretmenlere bilgi verilmiş ve çalışmaya katılımın tamamen gönüllülük esasına dayandığı vurgusu yapılmıştır. Özellikle o anda zihinsel yetersizlik tanısı almış öğrencilerle matematik öğretimi çalışan 21 (yirmi bir) öğretmen belirlenmiştir. Araştırmada her öğretmen için kod isim belirlenmiş ve gerçek isimleri çalışmanın hiçbir aşamasında kullanılmamıştır.

Araştırma verilerinin toplanması için alanyazında yapılan çalışmalar incelenerek ve dört uzman görüşü alınarak yarı yapılandırılmış görüşme tekniği ile hazırlanmış görüşme soruları oluşturulmuştur. Araştırmacı, görüşmeleri sağlıklı bir şekilde yürütebilmek amacıyla görüşmeler başlatılmadan önce bir görüşme formu hazırlamıştır. Görüşme formu, görüşmenin amacının ne olduğuna, araştırmanın nasıl yürütüleceğine, katılımcıdan neler beklendiğine, kayıt işleminin nasıl yapılacağına ve araştırma sonuçlarının nasıl kullanılacağına ilişkin açıklamaları içermektedir.

Görüşme soruları, görüşme formu ve kişisel bilgi formu hazırlandıktan sonra araştırmanın verilerini elde etmek amacıyla iki öğretmenle pilot çalışma yapılmıştır. Pilot görüşmelerde ses kayıt tekniği kullanılarak veriler kayıt altına alınmıştır. Formlarla birlikte yapılan görüşmelerin dökümleri alanda uzman iki kişi tarafından incelenmiş ve soruların araştırmanın amacına uygun olduğu kanısına varılmıştır.

Araştırmada elde edilen veriler içerik analizi tekniği ile analiz edilmiştir. İçerik analizi metin ya da metinlerden oluşan bir kümenin içeriğindeki bazı önemli kelime veya kavramların belirlenmesine yönelik yapılır (Büyüköztürk, Çakmak, Akgün, Karadeniz ve Demirel, 2009). İçerik analizi toplanan verilerin daha derin bir şekilde analiz edilmesini gerektirir ve daha önce 
belirgin olmayan boyutların ortaya çıkarılmasına olanak sağlar. İçerik analizinde temel amaç, toplanan verileri açıklayabilecek kavramlara ve ilişkilere ulaşmaktır (Yıldırım ve Şimşek, 2005).

Görüşmelerin hepsi tamamlandıktan sonra ses kayıtlarının yazıya dökümü işlemine geçilmiştir. Ses kayıtlarının yazıya aktarımı sırasında ses kaydındaki bütün konuşulanlar hiçbir düzeltme yapılmadan olduğu gibi yazıya aktarılmıştır. Ses kayıtlarının yazıya dönüştürüldüğü sayfalara ve sayfadaki her bir satıra numara verilmiştir. Dökümlerin doğruluğunu kontrol etmek amacıyla ses kayıtları tekrar dinlenmiş ve o esnada yazılan veriler okunarak verilerin eksiksiz olduğu görülmüştür.

Kategorilerin oluşturulmasında ağılıklı olarak görüşme soruları ön planda tutulmuştur. Örneğin görüşme soruları içerisinde yer alan "Öğrencilerin matematik beceri, kavram ve işlemlerinin değerlendirilmesinde ne tür sorunlarla karşılaşıyorsunuz?" sorusuna verilen cevaplar için; "Değerlendirmede karşılaşılan sorunlar" kategorisi oluşturulmuştur. Bu şekilde toplam 7 kod elde edilmiştir.

Kategoriler:

- Değerlendirmede yapılan uyarlamalar

- Materyallerde yapilan uyarlamalar

- Ortamda yapilan uyarlamalar

- Uyarlamalarda dikkat edilenler

- Öğrenci hatalarından nasıl yararlanıldığ

- Karş1laşılan sorunlar

- Sorunların çözümüne ilişkin yapılanlar

Kategoriler ve kodlar oluşturulduktan sonra temalar oluşturulmuştur. $\mathrm{Bu}$ merhalede araştırmacı görüşmelerin yazıya aktarıldığı dokümanları okuyarak başlıklar oluşturmuş ve aynı başlık altında toplayabileceği verileri bu başlıklar altında toplamıştır. Yapılan görüşmelerde öğretmenlerin konuşmalarından alıntılar yapılarak da veriler düzenlenmiştir. Bu işlemler sonucunda elde edilen başlıklar çalışmanın temalarını oluşturmuştur.

Temalar oluşturulduktan sonra alandan bir uzman rastgele seçilen üç görüşme dökümünü inceleyerek temalar oluşturmuştur. Araştırmacı ve uzman tarafından oluşturulan üç görüşme ile ilgili temalar karşılaştırılmış ve görüş birliği sağlanmıştır. Diğer görüşme dökümleri de incelenerek temaların oluşturulması araştırmacı ve uzman tarafından tamamlanmıştır. 


\section{Bulgular}

Bu bölümde, zihinsel engelli sınıf öğretmelerinin zihinsel yetersizliği olan öğrencilerin matematik beceri, kavram ve işlemlerini değerlendirme sürecinde yaptıklarının belirlenmesi amacıyla yarı yapılandırılmış görüşme tekniğiyle hazırlanmış sorulara verdikleri yanıtların analizinden elde edilen bilgilere yer verilmiştir. Araştırmanın bulguları 4 tema ve 3 alt temadan oluşmaktadır. Bu temalar şu şekilde sıralanmıştır:

1. Değerlendirme sürecinde yapılan uyarlamalar

a. Materyallerde yapilan uyarlamalar

b. Ortamda yapilan uyarlamalar

c. Uyarlamalarda dikkat edilenler

2. Öğrenci hatalarından nasıl yararlanıldığ 1

3. Değerlendirmede karşılaşılan sorunlar

4. Karşılaşılan sorunların çözümüne ilişkin yapılanlar

Temalara ilişkin bulgular tablo halinde aktarılırken, görüşmelerden alıntılar yapılarak temalarla ilgili örnekler verilmiştir.

\section{Değerlendirme Sürecinde Yapılan Uyarlamalar}

Değerlendirme sürecinde yapılan uyarlamalar üç alt temada incelenmiştir. $\mathrm{Bu}$ alt temalar, materyallerde yapılan uyarlamalar, ortamda yapılan uyarlamalar ve uyarlamalarda dikkat edilenler şeklindedir.

\section{Materyallerde Yapılan Uyarlamalar}

Öğretmenlere, materyal kullanımında yaptıkları uyarlamaları belirlemek için "Zihinsel yetersizliği olan öğrencilerin matematik beceri, kavram ve işlemlerini değerlendirirken materyallerde ne tür uyarlamalar yapıyorsunuz?" sorusu yöneltilmiştir. Öğretmenlerin bu soruyla ilgili verdikleri yanıtlar ve frekans dağılımları Tablo 1'de gösterilmiştir.

Tablo 1. Materyallerde Yapılan Uyarlamalar

\begin{tabular}{lc}
\hline Yapılan Uyarlamalar & Frekans \\
\hline Öğrenciye Uygun Materyal Hazırlama & 16 \\
Materyalleri Farklılaştırma & 3 \\
\hline
\end{tabular}

Tablo 1'de öğretmenlerin büyük çoğunluğunun materyalleri öğrenciye uygun olacak şekilde hazırladıkları görülmektedir. Üç öğretmenin, öğrencilerin ezber yapmasına ve sıkılmasına olanak vermemek için materyallerini farklılaştırdıkları, iki öğretmenin ise materyallerde herhangi bir uyarlama 
yapmadıkları ortay çıkmıştır.

Öğrencilerine uygun materyal hazırladıklarını, Bekir öğretmen, “ $\ddot{O} \breve{g}$ renciye zarar vermeyecek, ögrencinin daha kolay, daha basit, daha somut ögrenebileceği şekilde kendimizce hangi beceriyi çalışıyorsak ona göre ayarlama yapmaya çalışıyoruz."; Elif öğretmen, "Çocuğa göre materyal seçiyoruz. Mesela bir ögrencimiz var. Attan, kediden çok hoşlaniyor. At ă̆ırlıklı materyaller seçip ona göre değerlendirme soruyoruz."; İhsan öğretmen, "Materyalin işte en önemli özelliği fiziki özelliği işte bazı öğrencilerimizin görme problemi var. Bunlarda daha çok sesler işitsel uyarlamalar yapıyoruz. Kimisinin yanmada sikıntısı olabiliyor. Bunlara görsel olarak uyarlamalar yapıyoruz."; Taner öğretmen, "Materyalleri getiriyoruz. Materyalleri getirdikten sonra sırayla çocuklara tek tek baktırlyoruz, okutuyoruz onları. Öğrencilerin durumlarına göre sadeleştirme, basitleştirme yapıyoruz. Onlardan faydalanabiliyoruz."; Ülkü öğretmen, "Şu şekilde söyleyeyim, mesela sayı kartlarım var. Bunu bir ögrencim için 100'e kadar çıkarırken diğer bir ögrencim için 10'a kadar çıkarıyorum. Yani öğrenciye göre uyarlıyorum." şeklinde açıklamıştır.

Materyallerde farklılaştırma yaptıklarını, Mine öğretmen, "Bazen çalıştığım materyallerde sıkıntı oluyor. Materyalleri ezberleme yapmış oluyorlar. Ya da kullandiğım kartlarda ezberleme yapmış oluyorlar. O yüzden araç gereçlerimi değiştirmeye daha çok dikkat ediyorum. Farklı araç setlerini kullanıyorum. Farklı çalışma kă̆ıtları çıkarıyorum.”; Öykü öğretmen, "Hani hep aynı materyali kullanarak ona ezberlemiş mi diye baklyorum hani farkl materyalleri kullanarak ögrendiğini test ediyorum.”; Seçil öğretmen, “Öğretim yaptığımız materyalle bir sonraki açıdan değerlendirme yapıyoruz. Çocuğu kullandı̆̆ımı materyalle değil de hani sinuf ortamında ona benzer kavrama ya da ondan farklı şeylerle tanıştırmaya çalışıyoruz." açıklamasıyla ifade etmiştir.

Materyallerde uyarlama yapmadıklarını, Kemal öğretmen, "Öğrencileri değerlendirirken her çocuğa ayrı ayrı materyal hazırlamıyoruz.”; Pelin öğretmen, "Uyarlama yapmiyoruz." şeklinde ifade etmiştir.

\section{Ortamda Yapılan Uyarlamalar}

Öğretim ortamında yaptıkları uyarlamaları belirlemek için öğretmenlere "Zihinsel yetersizliği olan öğrencilerin matematik beceri, kavram ve işlemlerini değerlendirirken ortamda ne tür düzenlemeler yapıyorsunuz?" sorusu yöneltilmiştir. Öğretmenlerin bu soruyla ilgili verdikleri yanıtlar ve 
frekans dağılımları Tablo 2'de gösterilmiştir.

Tablo 2. Ortamda Yapilan Uyarlamalar

\begin{tabular}{lc}
\hline Yapılan Uyarlamalar & Frekans \\
\hline Dikkat Dağıtıcı Uyaranları Ortamdan Kaldırma & 6 \\
Bireysel Değerlendirme & 3 \\
Gruplandırma & 1 \\
\hline
\end{tabular}

Tablo 2'de altı öğretmenin dikkat dağıtıcı uyaranları ortamdan kald1rarak, üç öğretmenin öğrencileriyle bireysel çalışarak ve bir öğretmenin de öğrencileri seviyelerine göre gruplandırarak ortamda uyarlama yaptıkları görülmektedir. Öğretmenlerden on biri sınıfları müsait olmadığı için ortamda uyarlama yapmadıklarını dile getirmişlerdir.

Öğrencinin dikkatini dağıtan uyaranları kaldırarak ortam uyarlaması yaptıklarını, Bekir öğretmen, "Matematik öğretiminde ortamda çocuğun, ben kendi sınıfim için, dikkatlerini dağıtmayacak ne kadar sifirlayabilirsek, imkanlar dahilinde, tabi bu her zaman \%100 olmuyor, genelde çevre düzenlemesini bu şekilde yapıyorum. Hani çocuğun dikkatini sağa sola yöneltecek herhangi bir nesnenin, bir materyalin olmamasına dikkat etmeye çalışıyorum.”; Gamze öğretmen, "Ortam ögrencinin dikkatini dağıtacak unsurlardan arındırılıyor ve ögrenci için uygun hale getiriliyor."; Nalan öğretmen, "Uyarlamalar şimdi benim öğrencime bakarsanız bütün kavramlar sadece matematik değil bütün becerilerde dikkati çok dağınık bir ögrenci olduğu için genelde dikkatini dağıtmayacak bir ortamda sınıf ortamına arkası dönük önünde onun çok fazla görsel anlamda dikkatini çekmeyecek bir şekilde sinıf ortamını ancak öyle ayarlıyorum." şeklinde ifade etmiştir.

Ortam uyarlamasını öğrencilerle bireysel çalışarak yaptıklarını, Ceren öğretmen, "Ortamda fiziksel olarak çocukla yalnız çalışma önemli olan. Onun en iyi anlayabildiği yer orası."; Oya öğretmen, "Öğrencilerimden bir tanesi mesela fiziksel bir engeli var ortamı ona göre ya da diğer öğrencim birazcık daha akademik olarak geri düzeyde ikisini de birbirinden ayırabilecek bir şekilde tabi ortamı ve araç gereçleri ona göre düzenliyorum.”; Şule öğretmen, "Ĕger çocuk diğer arkadaşlarından etkileniyorsa o anda onu farkl bir odaya alıyoruz. O şekilde onunla bire bir çalışıyoruz. Ne kadar öğrendiğini test ediyoruz." şeklinde dile getirmiştir.

Öğrencileri gruplandırarak uyarlama yaptığını, Demir öğretmen, "Öğrencilerden seviyeleri birbirine yakın olanları yan yana oturtmaya çalı- 
şlyoruz. Mesela diğer ögretmenin belli ögrencileri var benim belli öğrencilerim var. O kendi ögrencilerini ben kendi ögrencilerimi yan yana oturtmaya çalışıyoruz ki değerlendirme yaparken iletişim kurmamız daha kolay olsun.” diyerek ifade etmiştir.

Öğrencilerin değerlendirilmesi sürecinde ortamda uyarlama yapmadıklarını, Elif öğretmen, "Ortamda düzenleme yapamıyoruz çünkü sınıf ortamımız buna müsait değil. Açıkçası sınıfımız çok dar, çok küçük.”; Faruk öğretmen, "Ortamda çok fazla bir düzenleme yapamıyoruz."; İhsan öğretmen, "Ortamımız zaten çok kısıtlı sinıfin metre kare olarak büyüklüğ̈̈ çok kısıtlı. Diğer öğrencilerle aynı zamanda öğretim yapmaya çalışırken değerlendirmeyi yapacağımız ögrenci ile çok fazla alana sahip olamıyoruz. Fiziksel olarak kısıtlı imkânlar olduğu için çok fazla düzenleme yapamıyoruz açıkçasl."; Mine öğretmen, "Ortamda çok fazla düzenleme, sinıfim kalabalık bir sınıf. Sekiz kişiyiz. Kalabalık olduğu için çok ortam düzenlemesine gidemiyorum." diyerek belirtmişlerdir.

\section{Uyarlamada Dikkat Edilenler}

Öğretmenlerin değerlendirme sürecinde yaptıkları çeşitli materyal ya da ortam uyarlamalarında nelere dikkat ettiklerini tespit etmek amacıyla öğretmenlere "Uyarlamaları yaparken nelere dikkat ediyorsunuz?" sorusu yöneltilmiştir. Öğretmenlerin bu soruyla ilgili verdikleri yanıtlar ve frekans dağılımları Tablo 3'te gösterilmiştir.

Tablo 3. Uyarlamalarda Dikkat Edilenler

\section{Dikkat Edilen Hususlar}

\section{Frekans}

Öğrenci Özelliklerine Dikkat Etme

20

Tablo 3'te materyal ve ortam uyarlamalarında, öğretmenlerden biri hariç diğerleri öğrenci özelliklerini göz önünde bulundurarak materyal veya ortam uyarlaması yaptığını ifade etmiştir. Uyarlamalara dikkat etmeyen bir öğretmen de materyal ve ortam uyarlaması yapmadığı için bu kategoride yer almaktadir.

Materyal ve ortam uyarlamalarında öğrenci özelliklerine dikkat ettiklerini, Aslı öğretmen, "Öğrenci seviyesine uygun uyarlamalar yapıyorum, bireysel farklılıklara bağll olarak uyarlamalar yaplyorum.”, Faruk öğretmen, "Öğrencinin neyi nasıl yapabildiğine bakarak uyarlama yapıyoruz. Mesela normalde programda daha detayl vermiş ama bizde o kadar detayl olmuyor.”; Gamze öğretmen, "Illk planda ögrencinin ihtiyacı söz konusu. Öğrenci 
hangi alanda çalışacak ona göre öğrenciye uygun materyaller hazırlaniyor. Ögrencinin zaafları dikkate alınıyor, zaafi olan bir materyal varsa onlar seçilip çıkartılıyor. Öğrencinin gelişimine uygun materyaller hazırlanıyor. Ortam ögrencinin dikkatini dağıtacak unsurlardan arındirlliyor, ögrrenciye uygun hale getiriliyor.”; İhsan öğretmen, "Öğrenciye göre uyarlama çalışıyoruz her ögrenciye ayrı değerlendirme yapmaya çalışıyoruz.”; Nalan öğretmen, “Öğrencinin özellikleri daha çok.”; Ülkü öğretmen,

“Öncelikle öğrencinin tanısı benim için çok önemli, ona çok dikkat etmek gerekiyor. Yani orta düzeydeki bir ögrenciye 10 tane materyal sunuyorsam, hafif düzeydekine 10 tane sunarsam çocuğun öğrenmem gereken seviyesini öğrenemem. O yüzden çocuğun tansina dikkat ediyorum. Çocuğun zeka yaşı bu çok önemli oluyor ve çocuğun gerçek yaşı. Belki zeka yaşı ile gerçek yaşı arasındaki fark daha düşükse ondan tam olarak verim alabilmek için bunların hepsine dikkat etmek zorunda kalıyoruz." şeklinde ifade etmiştir.

\section{Öğrenci Hatalarından Nasıl Yararlanıldı̆̆ı}

Öğrencilerin yaptıkları hataları göz önünde bulundurup bulundurmadıklarını ve bu hatalardan yola çıkarak öğretim ve değerlendirme süreçlerinde yaptıkları düzenlemeleri ortaya koymak için öğretmenlere "Zihinsel yetersizliği olan öğrencilerin matematik beceri, kavram ve işlemlerini değerlendirirken öğrencilerin yaptığı hatalarından nasıl yararlanıyorsunuz?" sorusu yöneltilmiştir. Öğretmenlerin bu soruyla ilgili verdikleri yanıtlar ve frekans dağglımları Tablo 4'te gösterilmiştir.

Tablo 4. Öğrenci Hatalarından Nasıl Yararlanıldı̆̆

\begin{tabular}{lc}
\hline Hatalardan Yararlanma & Frekans \\
\hline Öğretmenin Kendisini Kontrol Etmesi & 13 \\
Öğretmenin Öğrenciyi Kontrol Etmesi & 5 \\
Öğrencinin Kendisini Kontrol Etmesini Sağlama & 3 \\
\hline
\end{tabular}

Tabloda 13 öğretmenin, öğrencilerin yaptığı hatalardan kendi yaptıkları uygulamaları gözden geçirerek düzeltme yoluna giderek, beş öğretmenin öğrenci üzerinde bazı düzeltmeler yaparak, üç öğretmenin ise kendi yönlendirmeleriyle öğrencilerin kendi kendilerini düzeltmelerini sağlayarak öğrencilerin yaptıkları hatalardan yararlandıkları görülmektedir.

Öğretmenlerin kendilerini kontrol ettiklerini, Aslı öğretmen, "Ben kendime dönüyorum çünkü yaptığı hatalarda acaba çocuğa seviyesinden farklı bir şey mi vermişim? Ya da birbirinin ön koşulu olana beceriler var 
sonuçta, ön koşul becerileri verebilmis miyim? Bunlara dönüp kontrol ediyorum kendi içimde."; Ceren öğretmen, "Yaptı̆̆ bir hata bize aslında yol gösteriyor. Öğrenip ögrrenemediğini orda ögrenebiliyorum, kontrolünü bu şekilde yapabiliyorum. Bir daha o hatayl yapmaması için benim nasıl bir yol izlemem gerektiğini ben aslında anlıyorum.”; Gamze öğretmen, “Öğrencinin sık sık yaptığ hataları biz dikkate alarak bir daha o hatayı yapmaması için ya materyal değiştiriyoruz ya da ortamda öğrencinin dikkatini dağıtacak unsurlar varsa onları kaldırıyoruz."; Mine öğretmen, "Öğrencilerin yaptı̆̆ hatalar gerçekten bazen bana kendi hatalarımın da farkına varmama sebep olabiliyor. Baklyorum bazen mesela bir basamağı atlamış oluyorum çalıştığım grup kalabalık olduğu için. Bana da yol gösteriyor bazen. Farklı bir yöntem seçmeme neden oluyorlar. Yöntem seçmede bana yol gösteriyor diyebilirim."; Öykü öğretmen, "Hata yaptıklarında kendimde de bir hata artyorum. Acaba neden hani hata yapıyorlar diye kendi çapımca derse uygun hani değiştirerek yeri geldiğinde düzeltmeler yapıyorum.” ifadeleriyle belirtmiştir.

Öğretmenlerin öğrencilerini kontrol ettiklerini, Pelin öğretmen, “Öncelikle yaptıkları hatalardan hangi konuyu veya kavramı niye ögrenmedilerse onlar belirlemiş oluyoruz ögrenmediklerinin üzerine tekrar dönüyoruz öğrendiklerini devam ettiriyoruz."; Taner öğretmen, "Öğrencilerin yaptığ hatalart ileriye dönük olarak tekrarlama yöntemi uyguluyoruz. Bu tekrarlama yöntemi de zaten az önce sizinle paylaştı̆̆ım gibi bu çocuklar bugün ögretileni yarın unutabiliyorlar. Mümkün olduğu kadar sık tekrar uyguladı̆̆ımız zaman belli bir mesafeler almaya çalışıyoruz.” Kemal öğretmen,

“Öğrencilere geri dönütler veriyoruz sinavlardan sonra. Hangi öğrenci kaçar puan almış bunları çocuklarla paylaşırken çocuklar neden eksik aldlklarını soruyorlar diğer arkadaşlarına göre. O zaman diyoruz ki sen şu soruyu yapamamışsın. Nereyi yanlış yapmışım tekrar tahtada çözerek ya da çocukla baş başa çözerek çocuğun farkındalı̆ı̆ıı artırmaya çalışıyoruz." diyerek ortaya koymuşlardır.

Öğrencilerin kendilerini kontrol etmesini sağladıklarını, Demir öğretmen,

"Hatalart ögretimdeki gibi direk o anda düzeltme yoluna gitmiyorum. Değerlendirmede kaç tane aşama varsa hepsini yaptırtp ondan sonra en son hataların tek tek göstermeden daha doğrusu mesela eldeli toplam işleminden elli tane örnek vermişimdir yapması için değerlendirmede. Bunların kirk tanesini doğru yapmuştır, on tanesini yanlış yapmıştır. $O$ on tanesine eksi koyarım. Hatasını söylemem. Öğretim- 
deki gibi şu şu hataların var demem. Sadece bunlar yanlış bir daha gözden geçir derim.”,

Hacer öğretmen,

“Bence şöyle bir insan bir ögrencimizde olsa yanlış yaptı̆̆ında doğruyu ögrenme daha iyi oluyor. Yani doğruyu öğrenmeye bir adım daha yaklaşmış oluyor benim için o hataları değiştirebilmek için ögrenciyle hareket ediyoruz. Hataların özellikle dikkat çekici nerde hata yaptığını başını sonucunu ne gibi cevaplar verdiği bunu beraber değerlendiriyoruz. Ĕ̆er çocuk farkında değilse ona farkındalık yaratıyoruz." şeklinde bildirmiştir.

\section{Değerlendirmede Karşılaşılan Sorunlar}

Öğretmenlerin değerlendirme sürecinde karşılaştıkları sorunların neler olduğunu belirlemek için öğretmenlere "Öğrencilerin matematik beceri, kavram ve işlemlerinin değerlendirilmesinde ne tür sorunlarla karşılaşıyorsunuz?" sorusu yöneltilmiştir. Ayrıca öğretmenlerin bu sorunların üstesinden nasıl geldikleri bir alt temada incelenmiştir. Öğretmenlerin karşılaştıkları sorunlarla ilgili soruya verdikleri yanıtlar ve frekans dağılımları Tablo 5'te gösterilmiştir.

Tablo 5. Değerlendirmede Karşılaşılan Sorunlar

\begin{tabular}{lc}
\hline Sorunlar & Frekans \\
\hline Öğrencinin Dikkatinin Dağınık Olması & 5 \\
Öğrencinin Çalışmayla İlgilenmemesi & 4 \\
Araç-Gereç ve Materyal Eksikliği & 4 \\
Sınıf Ortamının Uygun Olmaması & 3 \\
Zamanın Yetmemesi & 3 \\
Öğrencinin Öğretileni Unutması & 2 \\
Farklı Seviyede Öğrencilerin Olması & 2 \\
Matematĭğ Soyut Olması & 2 \\
Öğrenci Seviyesine İnilememesi & 1 \\
\hline
\end{tabular}

Öğretmenlerden bazıları tek bir sorunla karşılaşırken bazıları da birden fazla sorunla karşılaştıklarını, iki öğretmen ise hiçbir sorunla karşılaşmadıklarını dile getirmiştir.

Öğrencilerin dikkatinin dağınık olması sorununa, Aslı öğretmen, "Birbirlerinin dikkatlerini dağıtmalar gibi durumlar olumsuz etkiliyor.”; Bekir öğretmen, "Çocuğun o anda herhangi bir nesneye, herhangi bir olaya, en ufak bir sese bile farklı tepki verdiğini biliyoruz.”; Demir öğretmen, "Bizim 
ögrrencilerin en büyük sıkıntısı dikkat dağınıklarının çok fazla olması.”; Elif öğretmen, "En büyük sorun dikkat eksikliği zaten.” diyerek; öğrencilerin çalışmayla ilgilenmemesi sorununa, Ceren öğretmen, "Çocuk bazen iletişime kapalı olabiliyor."; İhsan öğretmen, "O gün okula çok büyük sıkıntılarla gelmiş olabilir kendini hiçbir şekilde derse veremiyor.”; Leyla öğretmen, "Bizim ögrencilerimizde şöyle sorunlarla oluyor mesela çocuk anlayıp anlamadiğına bakacaksın ama çocuk yapmak istemiyor. Ben ders işlemek istemiyorum diyor. İste canım sıkıldı diyor. Hoplamak zıplamak istiyor. Böyle şeyler sıkıntı oluyor." diyerek; araç-gereç ve materyal eksikliği sorununa, Nalan öğretmen, "Materyal sıkıntısı yaşıyoruz. Bizim en büyük sıkıntımız o.”; Öykü öğretmen, "Ölçeğimiz yok. Ona uygun bir ölçek bulmak gerekiyor. Öğrencilere uygun bir ölçek bulmak gerekiyor." diyerek; sınıf ortamının uygun olmaması sorununu, Aslı öğretmen, "Sınıf ortamının darlı̆̆ı"; Bekir öğretmen, "Sınıf ortamının ögrenci özelliklerine göre donatılmaması" diyerek; zamanın yetmemesi sorununa, Demir öğretmen, "Her ögrrencinin seviyesinin farklı olması hepsiyle tek tek ilgilenmemizi gerektiriyor. Böyle olunca da zaman konusunda sıkıntı yaşıyoruz. Tek tek her öğrenciye istediğimiz zamanı ayıramıyoruz."; Mine öğretmen, "Zaman sikıntısı oluyor sinıf ortaminda" diyerek; öğrencinin öğretileni unutması sorununa, Seçil öğretmen, "Diğerini öğrettiğimizde bir önceki amacı karıştırıyor. Üstüne ekledikçe diğerleri karışıyor. Yani orada benim biraz sıkıntım var." diyerek; farklı seviyede öğrencilerin olması sorununa, Aslı öğretmen, "Farklı seviyelerde ögrencilerle çalışıyor olmak" diyerek; matematiğin soyut olması sorununa, Gamze öğretmen, "Matematikle ilgili beceriler biraz soyut kaldı̆g için öğrenci algılamak da zorluk çekiyor." diyerek; öğrenci seviyesine inilememesi sorununa, Elif öğretmen, "Çocuğun seviyesine inmek çok zor." diyerek değinmiştir.

Rıza öğretmen, "Bir sorunla karşılaşmadım hiç."; Şule öğretmen, "Sorunla karşılaşmıyoruz. Zaten onların anlayabileceği düzeyde değerlendirmeler yaptı̆̆ımı için sorun olmuyor." diyerek herhangi bir sorun yaşamadıklarını belirtmiştir.

\section{Karşılaşılan Sorunların Çözümüne İlişkin Yapılanlar}

Öğretmenlerin karşılaştıkları sorunların üstesinden gelmek için neler yaptıklarını öne çıkarmak adına "Karşılaştığınız sorunların çözümüne ilişkin neler yapıyorsunuz?" sorusu yöneltilmiştir. Öğretmenlerin bu soruyla ilgili verdikleri yanıtlar ve frekans dağılımları Tablo 6'da gösterilmiştir. 
Tablo 6. Sorunların Çözümüne İlişkin Yapılanlar

\begin{tabular}{lc}
\hline Çözüm Yolları & Frekans \\
\hline İşbirliği İçerisinde Çalışılması & 2 \\
Öğrencinin Dikkatinin Toplanması & 2 \\
Çalışmanın İlgi Çekici Hâle Getirilmesi & 2 \\
Çalışmanın Somut Hâle Getirilmesi & 2 \\
Materyal Alınması & 2 \\
Materyalin Değiştirilmesi & 2 \\
Materyalin Zenginleştirilmesi & 1 \\
Ortamın Değiştirilmesi & 1 \\
Öğretmenin Değiştirilmesi & 1 \\
Öğretimin Tekrar Edilmesi & 1 \\
Öğrencinin Ödüllendirilmesi & 1 \\
\hline
\end{tabular}

Tablo 6'da öğretmenlerin karşılaştıkları sorunlara farklı çözüm önerileri ile müdahale ettikleri görülmektedir. İki öğretmen, herhangi bir sorunla karşılaşmamaları nedeniyle sorunların çözümüne ilişkin de bir şey yapmadıklarını belirtmiştir.

İşbirliği içinde çalıştıklarını, Demir öğretmen, "Bu konuda benim ilk aklıma gelen en önemli şey işbirliği içinde ve koordineli çalışmak.”; Seçil öğretmen, "Birbirimizden en azından fikir allyoruz. Birbirimiz arasında yardımlaşma." ifadesiyle; öğrencinin dikkatini topladığını, Elif öğretmen, "Ne kadar çok materyal sunarsak çocuğun dikkatini çeker ve o kadar dikkatini toplayabiliyoruz." ifadesiyle; çalışmayı ilgi çekici hale getirdiğini, Faruk öğretmen, "Bunları işte daha fazla eğlenceli hale getirerek çocukların ilgisini çekecek şekilde merak uyandırarak bir şekilde performansını arttırmaya çalışıyoruz." ifadesiyle; çalışmayı somut hale getirdiğini, Gamze öğretmen, "Matematikle ilgili beceriler biraz soyut kaldı̆̆ için ögrenci algılamak da zorluk çekiyor illa ki bizde bunları somut hale getiriyoruz.” ifadesiyle; materyal aldığını, Nalan öğretmen, "Kendi imkânlarımızla alıyorsak ya da hazırlyyorsak oluyor.” ifadesiyle; materyali değiştirdiğini, Hacer öğretmen, "Materyali değistitiriyoruz. Ya da değerlendirme kâğıdı ögrenciye zor geldiyse biraz kolayını veriyoruz. Çünkü yanımızda bulunması gerekiyor kolay, orta, zor.” ifadesiyle; materyali zenginleştirdiğini, Oya öğretmen, "Araç gereci zenginleştirerek değerlendirme yapabileceğim ortamı zenginleştirerek değerlendirme ortamı hazırliyorum." ifadesiyle; ortamı değiştirdiğini, Aslı öğretmen, "Öğretimlerde sinıf içinde kalmıyoruz. Bina içerisinde en üst ka- 
tımız tamamen boş sınıflardan oluşuyor, o sınıflarda çalışıyoruz. Yani ortam değiştiriyoruz." ifadesiyle; öğretimi tekrar ettiğini, Ülkü öğretmen, "Tamamen resetleyen ögrenci içinse o konuyu tekrar başa almaktan başka zaten yapılacak hiçbir şey yok." ifadesiyle; öğrenciyi ödüllendirdiğini Taner öğretmen, "Ödüllendirme yaptı̆̆ımız zaman çocuğu biraz daha fazla tutabiliyoruz." ifadesiyle dile getirmiştir.

\section{Sonuçlar}

Araştırma kapsamında görüşme yapılan öğretmenlerden yirmisi değerlendirme sürecinde uyarlama yaptıklarını ve bu uyarlamaları yaparken de birtakım unsurlara dikkat ettiklerini belirtmişlerdir. Gerek materyal gerekse ortam uyarlaması olsun öğretmenlerin değerlendirme sürecinde değişiklikler yapması değerlendirme için önemli bir olgudur. Uyarlamaların temel amacı; öğrencilerin yapılan çalışmalara en üst düzeyde katılımlarını sağlamaktır. Bu durumda uyarlama, çeşitli değişikliklerin ve düzenlemelerin yapılması sürecini kapsamaktadır. Bu değişiklikler ve düzenlemeler; sınıf ortamında ve materyallerde yapılan düzenlemelerdir (Friend ve Bursuck, 2002).

Görüşülen öğretmenlerden on altısı kullandıkları materyallerde öğrenci özelliklerine uygun şekilde materyal hazırladıklarını bildirmişlerdir. Materyallerde farklılaştırma yapan üç ögretmen, öğrencilerin ezber yapmalarını ve çok çabuk sıkılmalarını engellemek adına bu yolu tercih ettiklerini dile getirmişlerdir. Materyallerde uyarlama yapmayan iki öğretmenden birinin alan dışından mezun olması ve matematik eğitimi ile ilgili herhangi bir eğitim almamış olması, diğer öğretmenin ise yine alan dışından mezun olması fakat özel eğitim alanında lisansüstü eğitim yapmış olması dikkat çekicidir. Vural'ın (2008) kaynaştırma sınıfı öğretmenlerinin öğretimin uyarlanmasına ilişkin yaptıkları çalışmaların belirlenmesi adlı çalışmasında öğretmenlerin yarısı kullandıkları materyallerde kaynaştırma öğrencisi için uyarlama yapmadıklarını belirtmişlerdir. Çalışmanın bu bulgusu araştırma bulgularımızla çelişmektedir. Öğretmenlerin kullandıkları materyaller üzerinde uyarlamalar yapmalar1 öğretim sürecini etkileyebilir. Öğrenciye uygun materyal kullanılması öğretimi yapılacak beceri, kavram ya da işlemin öğrenci tarafından daha etkili ve daha çabuk kazanılmasını sağlayabilir.

Ortamda uyarlama yapmayan on bir öğretmenin on tanesi, sınıflarının ebat olarak küçük ve öğrenci sayısı olarak kalabalık olması sebebiyle uyarlama yapamadıklarını ifade etmişlerdir. Önder (2007), sınıf öğretmenlerinin zihinsel yetersizliği olan kaynaştırma öğrencileri için sınıf içinde yaptıkları 
öğretimsel uyarlamaların belirlenmesine yönelik yaptı̆̆ ç̧alışmada, görüşme yapılan öğretmenlerin yarısından fazlasının özel gereksinimli öğrenci için sınıfta herhangi bir uyarlama yapmadıkları sonucuna ulaşmıştır. Önder'in çalışma bulgusu araştırma bulgularımızla örtüşmektedir. Buradan, okulların yapı olarak eski, sınıfların sonradan oluşturulduğu ya da binaların amacına uygun olarak yapılmadığı sunucuna ulaşılabilir.

Görüşmelerde öğretmenlerden altısı sınıf ortamında öğrencinin dikkatini dağıtacağını düşündüğü uyaranları ortadan kaldırarak ortam uyarlaması yaptığını belirtmiştir. Hall (2002), sınav uyarlamalarının özel gereksinimli bireylerin performanslarına etkisi konulu araştırmasında, özel gereksinimli öğrenciler için değerlendirme ortamında yapılan uyarlamaların öğrenci başarıları üzerinde etkisi olduğunu ortaya koymuştur.

Hem materyal hem de ortam uyarlamalarında, öğretmenlerden yirmisi öğrencilerin özelliklerine göre materyal veya ortam uyarlaması yaptıklarını dile getirmişleridir. Uyarlamalara dikkat etmeyen sadece bir öğretmen de hem materyal hem de ortam uyarlaması yapmadığı için bu kategoride yer almaktadir.

Öğrenciye uygun materyal ve ortam olmadan yapılan değerlendirme çalışmaları, öğretmenlerin belirledikleri beceri, kavram ya da işlemin öğrenci tarafından kazanılıp kazınılmadığı, yapılan öğretim planının uygun olup olmadığı sonucuna ulaşılmasını ve zamanın etkili bir şekilde kullanılmasını etkileyebilir. Öğretmenlerin uyarlamalara dikkat etmesinin değerlendirme sürecinin etkili olması açısından önemli olduğu düşünülmektedir. Gürgür (2005) gerçekleştirdiği çalışmada, özel gereksinimli öğrenciler için yapılan uyarlamalar sayesinde öğrencilerin derse daha etkili, istekli katıldığını ve bunun sonucunda da daha başarılı olduğu sonucuna varmıştır.

Öğrencilere matematik beceri, kavram ve işlemlerinin iyi bir biçimde kazandırılabilmesi için olası öğrenci hatalarının tespit edilmesi ve en aza indirgenmesi oldukça önemlidir (Gürsel, 2000). Öğretmenlerin hepsi öğrencilerin yaptıkları hataları dikkate aldıklarını ve bu hatalardan yola çıkarak, on üç öğretmen kendi yaptıklarını kontrol ettiklerini bildirmiştir. Öğrencilerin yaptıkları hataların dikkate alınması, öğrenciye özgü hazırlanmış olan programın geliştirilmesinde öğretmenlere büyük katkı sağladığı düşünülmektedir. Smith, Polloway, Patton ve Dowdy (2008) özel gereksinimli bireyler için matematik programında uyarlamalar yapılmasına gereksinim olduğunu belirtmektedirler. Çalışmaya katılan öğretmenlerin ifadelerinden, özel gereksi- 
nimli öğrencilerin matematik beceri, kavram ya da işlemlerinde yaptıkları hatalardan yeteri kadar yararlandıkları ve programın bireyselleştirilmesinde ve bireyselleştirilen programın geliştirilmesinde kullandıkları anlaşılmaktadır. Öğrencilerin öğrenme düzeylerinin ve gereksinimlerinin farklılık göstermesi halinde, yapılan öğretimin öğrenci için etkili olabilmesi, planlamada farklılıkların olmasını gerektirmektedir (Tekin-İftar, 2005).

Kendisiyle görüşülen öğretmenler karşılaştıkları sorunların en başında özel gereksinimli öğrencilerin dikkatlerinin dağınık olması, yapılan çalışmayla ilgilenmemeleri ve materyal eksiği sorunlarının geldiğini vurgulamışlardır. Sliva (2004) yaptığı araştırmada düşük başarı seviyesine sahip öğrencilerin matematik derslerine düşük düzeyde katılabildiklerini belirlemiştir. $\mathrm{Bu}$ bulgu, araştırmada elde edilen bulgularla örtüşmektedir. Öğretmenler ayrıca zamanın yetmediğini bildirmişlerdir. Vaughn, Bos ve Schumm (2005), öğrenme güçlügü olan öğrencilerin akranlarına oranla daha fazla zamana ve tekrara ihtiyaç duydukları sonucuna varmaları araştırmanın bulgularıyla tutarlılık göstermektedir. Zamanının yeterli olmaması sorunu, öğretmenlerin zihinsel yetersizliği olan öğrencilerin değerlendirilmesi çalışmalarına sınıflarının kalabalık olması nedeniyle yeteri kadar zaman ayıramadıkları ve tekrar yapamadıkları bulgusunu elde eden Güven (2009) tarafından desteklenmektedir. Ayrıca sınıf ortamının uygun olamaması ve sınıfta farklı seviyelerde öğrencilerin olması gibi birçok sorunun, öğretmenlerin öğrencilere ulaşımını zorlaştırdığı düşünülmektedir.

Çimen (2009), eğitim uygulama okuluna devam eden zihinsel engelli öğrencilerin öğretmenlerinin bireyselleştirilmiş eğitim programı hakkında görüşlerinin belirlenmesi adlı çalışmasında öğretmenlerin karşılaştıkları güçlükler arasında, araç-gereç eksikliği, fizikî şartların yetersizliği ve zaman (süre) eksikliğinin yer alması araştırma bulgularımızı destekler niteliktedir.

Karşılaşılan sorunların çözümüne ilişkin yaptıkları uygulamalara yönelik sorulan soruya öğretmenler, diğer öğretmenlerle işbirliği yaparak, materyal sayısını ve çeşidini arttırıp öğrencinin dikkatini toplayarak ve çalışmayı ilgi çekici hale getirerek, ortamı değiştirerek, öğretmeni değiştirerek ve öğrenciyi ödüllendirerek sorunlara çözüm bulmaya çalıştıklarını belirterek yanıtlamışlardır. Bunların dışında çalışmayı daha somut hale getirdiklerini ve öğretimi tekrarladıklarını belirtmişlerdir. Öğretmenlerin çok büyük kısmının sorunları aşmak için çaba sergilemeleri, özel gereksinimli öğrenciler adına ellerinden geleni yapma isteği içerisinde olduklarını düşündürmektedir. Öğ- 
retmenlerin bu davranışları etkili değerlendirme uygulamaları açısından önemli olabilir.

Sonuç olarak öğretmenler, özel gereksinimli bireylere yeni bir beceri, kavram ya da işlem öğretimi kararının alınmasında değerlendirme sürecinin öneminin farkındadırlar. Elde edilen veriler, öğretmenlerin, zihinsel yetersizliği olan öğrencilerin matematik beceri, kavram veya işlemlerinin değerlendirilmesi konusunda gerekli özeni gösterdiklerini ortaya koymaktadır. Öğretmenlerin değerlendirme aşamasında karşılaştıkları sorunları kendi çabalarıyla aşmaya çalıştıkları görülmektedir. Fakat gerekli desteğin sağlanması hâlinde değerlendirme çalışmalarının daha iyi hâle gelebileceğini ve özel gereksinimli öğrenciler için daha etkili bir çalışma olacağının vurgusunu yapmaktadırlar.

\section{Öneriler}

Bu bölümde araştırmanın bulguları doğrultusunda uygulamaya ve ileride yapılacak araştırmalara yönelik öneriler yer almaktadır.

\section{Uygulamaya Yönelik Öneriler}

Öğretmenlere, zihinsel yetersizliği olan öğrencilerin matematik beceri, kavram ya da işlemlerini değerlendirme sürecinde değerlendirme aracı kullanmaları ve özel eğitim alanındaki yenilikler ve değişikliklerle ilgili belirli aralıklarla bilgi verilebilir. Öğretmenler, meslektaşları, okul yönetimleri ve öğretmen yetiştiren kurumlarla işbirliği içerisinde çalışabilirler. Öğretmenlere, öğrencilerin matematik beceri, kavram ve işlemlerini değerlendirme sürecinde kullanabilecekleri materyal desteği sağlanabilir. Sınıfların fiziksel koşulları öğrencilerin değerlendirilmesi sürecinde daha uygun hale getirilebilir. Okul yönetimleri, öğretmenler ile işbirliği içerisinde çalışabilir ve öğretmenlere değerlendirme sürecinde kullanabilecekleri materyal desteğini sağlayabilir.

\section{İleri Araştırmalara Yönelik Öneriler}

Zihinsel yetersizliği olan öğrencilerin matematik beceri, kavram ve işlemlerinin öğretim öncesi, öğretim anı ve öğretim sonunda değerlendirilmesiyle performanslarındaki değişim ve ilerlemeye ilişkin çalışmalar yapılabilir. Zihinsel yetersizliği olan öğrencilerin matematik beceri, kavram ve işlemlerinin değerlendirilmesinde öğretmenlerin hazırladıkları değerlendirme araçları ile standart değerlendirme araçlarından elde edilen veriler karşılaştırılabilir. Gözlem ve doküman incelemesi veri toplama teknikleri kullanılarak öğretmenlerin zihinsel yetersizliği olan öğrencilerin matematik beceri, kav- 
ram ve işlemlerinin değerlendirilmesi sürecinde yaptıkları belirlenebilir. Öğretmenlerin, farklı derslerde, zihinsel yetersizliği olan öğrencileri değerlendirme sürecinde yaptıkları araştırılabilir. Araştırma daha fazla öğretmene ulaşılarak gerçekleştirilebilir. Diğer yetersizlik gruplarının matematik beceri, kavram ve işlemlerinin değerlendirilmesi sürecinde öğretmenlerin yaptıkları uygulamaların neler olduğuna yönelik çalışma yapılabilir.

\section{Kaynakça}

Akkaya, R. (2006). Illköğretim altıncı sinıf ögrrencilerinin cebir ögrenme alanında karşılaşılan kavram yanılgılarının giderilmesinde etkinlik temelli yaklaşımın etkililiği. Yayınlanmamış yüksek lisans tezi, Abant İzzet Baysal Üniversitesi Sosyal Bilimleri Enstitüsü.

Bryant, D. P., Smith, D. D. ve Bryant, B. R. (2008). Teaching student with special needs in inclusive classrooms. USA: Pearson Education Inc.

Büyüköztürk, Ş., Çakmak, E. K., Akgün, Ö. E., Karadeniz, S. ve Demirel, F. (2009). Bilimsel araştırma yöntemleri (4. bask1). Ankara: Pegem Yayincilik.

Cawley, J. F. ve Parmar, R. S. (2003). Mathematics assessment for students with mild disabilities: Frameworks and practices. Learning Disabilities: A Contemporary Journal, 1(1), 20-26.

Çimen, C. (2009). Eğitim uygulama okuluna devam eden zihinsel engelli ögrencilerin ögretmenlerinin bireyselleştirilmiş eğitim programı hakkında görüşlerinin belirlenmesi. Yayınlanmamış yüksek lisans tezi, Bolu Abant İzzet Baysal Üniversitesi Sosyal Bilimler Enstitüsü.

Eckert, T. L., Dunn, E. K., Codding, R. S., Begeny, J. C. ve Kleinmann, A. E. (2006). Assessment of mathematics and reading performance: An examination of the correspondence between direct assessment of student performance and teacher report. Psychology in the Schools, 43(3), 247-265.

Friend, M. ve Bursuck, W. D. (2002). Including students with special needs: A practical guide for classroom teachers. Boston: Allyn and Bacon.

Gürgür, H. (2005). Kaynaştırma uygulamasının yapıldığı ilköğretim sınıfında işbirlikçi öğretim yaklaşımının incelenmesi. Yayınlanmamış doktora tezi, Ankara Üniversitesi Eğitim Bilimleri Enstitüsü. 
Gürsel, O. (2000). Hata analizi yoluyla zihin özürlü öğrencilerin dört işlemde yaptıkları hataların sınıflandırılması. Anadolu Üniversitesi Ĕgitim Fakültesi Dergisi, 10(2), 127-143.

Gürsel, O. (2010). Özel eğitimde değerlendirme. İ. H. Diken, (Ed.), Özel eğitime gereksinimi olan öğrenciler ve özel eğitim (3. bask1) içinde (29-58). Ankara: Pegem Akademi.

Güven, D. (2009). Illköğretimde kaynaştırma uygulamalarına katılan zihinsel yetersizliği olan öğrencilerin başarılarının değerlendirilmesine ilişkin ögretmen görüşleri. Yayınlanmamış yüksek lisans tezi, Anadolu Üniversitesi Eğitim Bilimleri Enstitüsü.

Hall S. E. H. (2002). The impact of test accommodations on the performance of students with disabilities. Yayınlanmamış doktora tezi, The George Washington University Faculty of the Graduate School of Education and Human Development.

Hanzlicek, V. A. (2006). The Kansas alternate assessment and instructional planning for special education teacher: A case study of implications for students with severe disabilities. ProQuest Information and Learning Company, (UMI No. 304356).

Huebner, K. M. (2000). Visual impairment. M. C. Holbrook ve A. J. Koenig (Ed.), Foundations of education: History and theory of teaching children and youths with visual impairments (2. bask1) içinde (55-76). New York: American Foundation for the Blind Press.

Karabulut, A. ve Yıkmış, A. (2010). Zihin engelli bireylere saat söyleme becerisinin öğretiminde eşzamanlı ipucuyla öğretimin etkililiği. Abant İzzet Baysal Üniversitesi Eğitim Fakültesi Dergisi, 10(2), 103-113.

Karasar, N. (2003). Araştırmalarda rapor hazırlama. Ankara: Nobel Yayın Dağıtım.

Kırcaali-İftar, G. (1996). Özel eğitimde değerlendirme. Anadolu Üniversitesi Eğitim Fakültesi Dergisi, 6(2), 89-93.

Önder, M. (2007). Sinıf öğretmenlerinin zihin engelli kaynaştırma öğrencileri için sınıf içinde yaptıkları ögretimsel uyarlamaların belirlenmesi. Yayınlanmamış yüksek lisans tezi, Abant İzzet Baysal Üniversitesi Sosyal Bilimler Enstitüsü. 
Pierangelo, R. ve Giuliani, G. A. (2009). Assessment in special education: a practical approach (3. bask1). New Jersey: Pearson Education Inc.

Salvia, J. ve Ysseldyke, J. (1988). Assessment in special and remedial education (4. bask1). Boston: Houghton Mifflin Company.

Sliva, J. A. (2004). Teaching inclusive mathematics to special learners. California: Corwin Pres.

Smith, T. E. C., Polloway, E. A., Patton, J. R. ve Dowdy, C. A. (2008). Teaching students with special needs in inclusive settings (5. bask1). USA: Pearson Education Inc.

Tekin-İftar, E. (2005). Etkili öğretim. A. Ataman (Ed.), Özel gereksinimli çocuklar ve özel eğitime giriş içinde (85-97). Ankara: Gündüz Eğitim Yayınc1lik.

Taylor, R. L. (2006). Assessment of exceptional students: Educational and psychological procedures (7. bask1). Boston: Allyn and Bacon.

Vaughn, S. R., Bos, C. S. ve Schumm, J. S. (2005). Teaching students who are exceptional, diverse and at risk in the general education classroom (5. bask1). USA: Pearson Education.

Vural, M. (2008). Kaynaştırma sınıfi ögretmenlerinin öğretimin uyarlanmasına ilişkin yaptıkları çalışmaların belirlenmesi. Yayınlanmamış yüksek lisans tezi, Abant İzzet Baysal Üniversitesi Sosyal Bilimler Enstitüsü.

Yıldırım, A. ve Şimşek, H. (2005). Nitel araştırma yöntemleri. Ankara: Seçkin Yayıncılik 